\title{
Cloning and Expression of a Novel Phytase Gene (phyMS) from Mycobacterium smegmatis
}

\author{
Tamrin Nuge1, Yumi Zuhanis Has-Yun Hashim ${ }^{1,2}$, Abd-El Aziem Farouk ${ }^{3}$, \\ Hamzah Mohd Salleh1,2* \\ ${ }^{1}$ Bioprocess and Molecular Engineering Research Unit, Department of Biotechnology Engineering, International \\ Islamic University Malaysia, Kuala Lumpur, Malaysia \\ ${ }^{2}$ International Institute for Halal Research \& Training, International Islamic University Malaysia, Kuala Lumpur, \\ Malaysia \\ ${ }^{3}$ Department of Biotechnology, Faculty of Science, Taif University, Taif, Saudi Arabia \\ Email: ${ }^{*}$ hamzah@iium.edu.my
}

Received 24 December 2013; revised 26 January 2014; accepted 5 February 2014

Copyright @ 2014 by authors and Scientific Research Publishing Inc.

This work is licensed under the Creative Commons Attribution International License (CC BY).

http://creativecommons.org/licenses/by/4.0/

(c) (1) Open Access

\section{Abstract}

Phytase, also known as phytate-degrading enzyme, catalyzes the hydrolysis of phytate (inositol hexakisphosphate) with sequential release of phosphate and lower inositol phosphate. We report here a new plasmid construct designated as pMSuia from pBAD-TOPO that harbors a $1.1 \mathrm{~kb}$ phytase gene (phyMS) from Mycobacterium smegmatis, and expression as well as characterization of the purified recombinant $M$. smegmatis phytase. DNA sequencing analysis and multiple alignment exercise indicated that the $M$. smegmatis phytase is different from both known acid and alkaline phytases. The active $\sim 45 \mathrm{kDa}$ recombinant enzyme was expressed and confirmed by enzyme assay and Western blot analyses. Ni-NTA affinity purified recombinant $M$. smegmatis phytase exhibited specific activity of $233.51 \mathrm{U} / \mathrm{mg}$, optimal $\mathrm{pH}$ of 3 and 7 and optimal temperature of $60^{\circ} \mathrm{C}$. The purified enzyme retains almost $30 \%$ of the initial activity after incubation at $90^{\circ} \mathrm{C}$ for $60 \mathrm{~min}$. The enzyme showed broad substrate specificity with $K_{m}$ and $V_{\max }$ of the recombinant enzyme for sodium phytate substrate of $0.105 \pm 0.016 \mathrm{mM}$ and $26.93 \pm 1.21 \mathrm{mM} \mathrm{min}^{-1}$, respectively.

\section{Keywords}

Mycobacterium smegmatis; Thermostability; Phytase; Broad pH Activity; Broad Substrate Specificity

\footnotetext{
"Corresponding author.
} 


\section{Introduction}

Phytases (myo-inositol hexaphosphate phosphohydrolase) are classified as phosphatases that catalyze the stepwise phosphate splitting of phytate or phytic acid (IP6), a major storage form of organic phosphorus in plant and seed grains, to lower inositol phosphate ester and phosphate. Microbial phytase application in the feed can reduce phosphorus excretion in monogastric animals by up to 50\%, which would significantly contribute towards environmental protection [1]. Phytase supplementation also leads to improving availability of minerals and trace elements [2]. In addition, phytases are used in foods as excellent bread-making improver [3] and also important for production of myo-inositol phosphates leading to development of pharmaceutical and chiral building blocks [4].

The major concerns in phytase production as animal feed are to produce enzymes that is able to effectively release phytate phosphate in the animal digestive tract, stable to resist inactivation by heat from feed processing and storage, and economically viable to produce. The search for naturally occurring phytases having the required level of thermostability and broad $\mathrm{pH}$ activity is ongoing. It is therefore the interest of the study to develop recombinant bacterial phytase exhibiting the desirable characteristics including thermostability and broad pH activity, to have potential industrial application. Many microbial phytases from fungal and bacterial sources have been successfully cloned and expressed in various bacteria, fungi and plants' hosts for industrial applications [5]-[8]. As part of our ongoing work on phytase, we report here the cloning of a 1.1 kb phytase gene (phyMS) from Mycobacterium smegmatis, the expression of this gene in E. coli as well as characterization of the purified recombinant $M$. smegmatis phytase.

\section{Materials and Methods}

\subsection{Bacterial Strains}

The genomic DNA of Mycobacterium smegmatis was purchased from ATCC (American Type Culture Collection, ATCC 23037D-5). Escherichia coli strain DH5 $\alpha$ was obtained from Invitrogen, USA.

\subsection{Phytase Gene Amplification, Cloning and Plasmid Construction}

The DNA encoding phytase was amplified by PCR technique [9] from total genomic DNA of M. smegmatis (ATCC 23037D-5) using the forward primer 5'-ATG GGT ATG AAT CCG CTT TTC CGG-3’ (TamMSF1) and reverse primer 5'-TCC ACT CCT CGG CAA CGC G-3’ (TamMSR4) designed from DNA sequence encoding a hypothetical protein sequence corresponding to a phytase from Mycobacterium smegmatis str. MC2 155 (NCBI accession No. YP_885178). The reaction system (50 $\mu \mathrm{l})$ consisted of $0.25 \mu \mathrm{l}$ of HotStarTaq DNA polymerase (Qiagen, Germany), $5 \mu \mathrm{l}$ of 10x PCR buffer, $1 \mu \mathrm{l}$ of $10 \mathrm{mM}$ dNTP mix, $5 \mu \mathrm{l}$ of $10 \mu \mathrm{g} / \mathrm{ml}$ of template DNA, $2.5 \mu \mathrm{l}$ of $10 \mu \mathrm{M}$ of TamMSF1, $2.5 \mu \mathrm{l}$ of $10 \mu \mathrm{M}$ of TamMSR4 and $33.75 \mu \mathrm{l}$ of dd $\mathrm{H}_{2} \mathrm{O}$. The conditions of phytase gene amplification were as follows: initial activation step at $95^{\circ} \mathrm{C}$ for 15 minutes, denaturation at $94^{\circ} \mathrm{C}$ for 1 minute, annealing temperature at $50^{\circ} \mathrm{C}$ for 45 seconds, extension at $72^{\circ} \mathrm{C}$ for 1.5 minutes and final extension at $72^{\circ} \mathrm{C}$ for 10 minutes. PCR was run for 34 cycles using Mastercycler ${ }^{\circledR}$ Gradient (Eppendorf, Germany). The correct size amplicon was designated as phyMS gene and was purified using QIAQuick Gel Extraction Kit (Qiagen, Germany). The purified phyMS gene was then inserted into pBAD-TOPO (Invitrogen, USA) for cloning and protein expression. The pBAD-TOPO used in this study contained 3'-thymidine (T) overhangs for TA cloning. Since, HotStarTaq DNA polymerase has a non template-dependent terminal transferase activity that adds a single deoxyadenosine (A) to the 3' ends of PCR products (phyMS), thus allow the ligation between the PCR inserts and the vector at the T-overhang efficiently in the absence of T4 DNA ligase. The successful ligation of pBAD-TOPO-phyMS is designated as pMSuia.

\subsection{Transformation, Screening and Sequencing}

The recombinant DNA plasmid construct pMSuia was transformed into E. coli DH5 $\alpha$ and cultured onto Luria Bertani (LB) agar plates that contain $100 \mu \mathrm{g} / \mathrm{ml}$ ampicillin [9] and was grown at $37^{\circ} \mathrm{C}$ for 16 hrs. The colonies from the plates were selected and cultured overnight in LB broth at $37^{\circ} \mathrm{C}$ and $200 \mathrm{rpm}$. pMSuia was extracted from the overnight culture (Qiagen Plasmid Midi Kit, Germany) and subjected to restriction enzyme digestion using NcoI and PmeI, as well DNA sequencing analysis (Macrogen, South Korea) using primers pBAD forward 
(5'-ATG CCA TAG CAT TTT TAT CC-3'), pBAD reverse (5'-GAT TTA ATC TGT ATC AGG-3'), TamMSF1 and TamMSR4.

\subsection{Protein Expression of Recombinant Phytase in E. coli DH5 $\alpha$}

E. coli that harbored pMSuia plasmid construct was cultured aerobically in 1 liter flask with $250 \mathrm{ml}$ LB broth containing $100 \mu \mathrm{g} / \mathrm{ml}$ ampicillin, at $200 \mathrm{rpm}$ and $37^{\circ} \mathrm{C}$. The cultures were induced with $0.02 \%(\mathrm{v} / \mathrm{v}) \mathrm{L}$-arabinose when $\mathrm{OD}_{600 \mathrm{~nm}}$ reached 0.6 (cells at the middle of the $\log$ phase). The bacteria cultures were harvested 6 hours after the induction time by centrifugation (Eppendorf, Germany) at $5000 \times g$ for 7 min. The supernatant was discarded and the cell pellet was suspended in $20 \mathrm{mM}$ Tris- $\mathrm{HCl}, \mathrm{pH} 8.0$ (approximately $1 \mathrm{ml} / \mathrm{g}$ wet cells).

\subsection{Enzyme Recovery and Purification}

The cell suspension was sonicated on ice for 3 min (cycles: 0.5, amplitude: 20; Labsonic M-Sartorius, Germany). Cellular debris was removed from the cell lysate by centrifugation at $\sim 20000 \times g$ for $45 \mathrm{~min}$ at $4^{\circ} \mathrm{C}$. The clear supernatant $(20 \mathrm{ml})$ was subjected to fast protein liquid chromatography (GE Healthcare, USA) [10] at $1 \mathrm{ml} / \mathrm{min}$. A glass column $(1.5 \mathrm{~cm} \times 10 \mathrm{~cm}$, Biorad, USA) packed with $8 \mathrm{ml}$ bed volume of Ni-NTA resin (Qiagen, Germany) was equilibrated with wash buffer (20 mM Tris-HCl pH 8.0 containing $1 \mathrm{M} \mathrm{NaCl})$. The column was eluted with wash buffer before elution buffer ( $20 \mathrm{mM}$ Tris- $\mathrm{HCl} \mathrm{pH}$ 8.0, containing $1 \mathrm{M} \mathrm{NaCl}$ and $250 \mathrm{mM}$ imidazole) was introduced. The purified recombinant enzyme was recovered for further analysis.

\subsection{Phytase Assay}

Phytase enzyme assay was performed according to Greiner [11] with minor modification. Phytase activity was determined at $55^{\circ} \mathrm{C}$ in the presence of $1.03 \mathrm{mM}$ sodium phytate (final concentration) dissolved in $100 \mathrm{mM}$ sodium acetate $\mathrm{pH}$ 4.5. The enzymatic reaction was initiated by addition of $50 \mu 1$ enzyme solution to the assay mixture to a final volume of $400 \mu \mathrm{l}$. After $30 \mathrm{~min}$ incubation at $55^{\circ} \mathrm{C}$, the liberated phosphate was measured according to the ammonium molybdate method [12]. One and half milliliter of freshly prepared solution of acetone: $2.5 \mathrm{M}$ sulfuric acid:10 mM ammonium molybdate $(2: 1: 1 \mathrm{v} / \mathrm{v})$ and thereafter $100 \mu \mathrm{l}$ of $1.0 \mathrm{M}$ citric acid were added to $400 \mu \mathrm{l}$ of the enzyme reaction mixture. Any cloudiness was removed by centrifugation prior to spectrophotometric measurement at $355 \mathrm{~nm}$ (ANTHELie, France). The activity (U) was expressed as $1 \mu \mathrm{mol}$ phosphate liberated per minute under the experimental conditions. Control assays were conducted by the addition of molybdate solution prior to addition of enzyme sample into the assay mixture. The phytase activity was calculated from the average of at least three phytase assay measurements.

\subsection{Effect of $\mathrm{pH}$ and Temperature on Purified Phytase Activity and Stability}

The phytase activity against the sodium phytate substrate was measured over a pH range of 2 to 11 in $100 \mathrm{mM}$ of the following buffers: glycine- $\mathrm{HCl}(\mathrm{pH} 2-3)$, sodium acetate- $\mathrm{HCl}(\mathrm{pH} 3-6)$, Tris-acetate ( $\mathrm{pH} 6$ - 7), Tris-HCl (pH 7 - 9) and glycine- $\mathrm{NaOH}(\mathrm{pH} 8$ - 11). The purified enzyme was diluted to $0.3 \mu \mathrm{g}$ and incubated at $55^{\circ} \mathrm{C}$ for $30 \mathrm{~min}$ in the presence of $1.03 \mathrm{mM}$ sodium phytate (final concentration) dissolved in the respective buffers into $400 \mu \mathrm{l}$ final volume. Subsequently, phytase activity of each enzyme solution was assayed as described earlier. All runs were carried out in triplicates. The optimal temperature for phytase was determined by incubating $0.3 \mu \mathrm{g}$ of purified enzyme at temperatures ranging from $35^{\circ} \mathrm{C}$ to $90^{\circ} \mathrm{C}$, in $100 \mathrm{mM}$ sodium acetate at pH 4.5 and $1.03 \mathrm{mM}$ sodium phytate (final concentration) to a final volume of $400 \mu \mathrm{l}$. The enzyme mixture was incubated for $30 \mathrm{~min}$ in each selected temperature. All runs were conducted in triplicates. For thermal stability study, the purified enzyme was incubated at $60^{\circ} \mathrm{C}, 70^{\circ} \mathrm{C}, 80^{\circ} \mathrm{C}$ and $90^{\circ} \mathrm{C}$ respectively. The residual enzyme activity was measured by taking aliquot ( $50 \mu \mathrm{l}$ ) every $10 \mathrm{~min}$ for $60 \mathrm{~min}$ duration and assayed as described above.

\subsection{Effect of Substrate Specificity and Kinetic Studies}

The substrate specificity of the purified recombinant M. smegmatis phytase was tested against $1.03 \mathrm{mM}$ (final concentration) of different phosphate containing compounds: phytic acid, AMP, ADP, ATP, NADP, naphthyl acid phosphate, $p$-nitrophenyl phosphate, D-fructose 1, 6 bisphosphate and pyridoxal-5-phosphate. The kinetic parameters were determined from the Lineweaver-Burk plot using SigmaPlot version 12 (Systat Software Inc., 
USA) with different concentrations of sodium phytate $(0.02$ - $1 \mathrm{mM})$. All experimental data were means of triplicate determination.

\section{Results and Discussion}

\subsection{Cloning of Phytase Gene (phyMS) from Mycobacterium smegmatis}

PCR was performed to isolate and amplify a phytase gene from M. smegmatis genomic DNA. A 1.1 kb phytase gene from $M$. smegmatis was successfully amplified. The amplicon contained no stop codon since the reverse primer, TamMSR4, was intentionally designed by replacing the "TGA" (encoding stop codon) to "GGA" (encoding glycine). This was to ensure expression of the special six Histidine tag (6xHis) at the C-terminus. The newly amplified phytase gene from M. smegmatis is designated as phyMS throughout the study. The PCR product was then gel purified and ligated into pBAD-TOPO (Invitrogen, USA) to yield a new plasmid construct, pMSuia, harboring the phyMS gene. The pMSuia plasmid construct was then transformed into competent $E$. coli DH5 $\alpha$ cells for over-expression. Both analysis by colony PCR and restriction enzymes digestion confirmed the presence of phyMS gene in the transformants.

\subsection{DNA Sequencing and Analysis of M. smegmatis Phytase Gene}

The DNA sequencing of the phyMS gene from pMSuia plasmid was outsourced to Macrogen (South Korea), and sequencing was conducted at both ends using pBAD priming, TamMSF1 and TamMSR4. The DNA sequencing results showed that the insertion of the phyMS gene was in frame with the DNA sequence coding for the 6xHis tag at the 3' end of the pBAD-TOPO (Invitrogen, USA). This tag permits the detection of the fusion protein by anti-His tag and aids purification by using Ni-NTA resin during enzyme recovery. The results were then translated into protein sequence by EXPASY Translate (http://expasy.org/tools/dna.html) before comparing with the existing putative $M$. smegmatis MC2 155 protein available in NCBI. The deduced amino acids from pMSuia plasmid construct showed 13 amino acids changes (apart from the directional mutations of stop codon "-" to glycine "G") compared to the existing putative M. smegmatis MC2 155 available in the public databases (Figure 1(a)). The thirteen deduced amino acid changes from pMSuia plasmid could be underlining the different taxonomic positions and strain variation of M. smegmatis MC2 155 in the database against the ATCC 23037D-5 strain used in this study.

Based on the deduced amino acid sequence, the molecular mass of recombinant $M$. smegmatis phytase inclusive of the linking amino acids and 6xHis tag is estimated to be $44.1 \mathrm{kDa}$ with $\mathrm{pI}$ of 5.1 as calculated by Compute $\mathrm{pI} / \mathrm{Mw}$ tool within EXPASY (http://expasy.org/tools/pi tool.html). The deduced amino acid sequence of the M. smegmatis phytase was aligned with the acidic phytases available in NCBI (http://blast.ncbi.nlm.nih.gov/) protein database by using ClustalW2 program (http://www.ebi.ac.uk/tools/msa/clustalw2/). M. smegmatis phytase is not homologous to the common acid phosphatase active site, RHGXRXP motif and the catalytic active dipeptide HD motifs (Figure 1(b)). The histidine residue in the RHGXRXP motif of acid phosphatase was demonstrated to be the nucleophilic acceptor of the phosphate group [13], whereas the HD dipeptide is involved in the protonation of the phytate residue by the aspartic acid in the motif [14]. The multiple alignments of the alkaline phytases especially from the Bacillus species show neither homologous to the M. smegmatis phytase (Figure 1(c)) nor to hepta-peptide motif RHGXRXP or the catalytic active dipeptide HD [15]. The properties of the $M$. smegmatis phytase will be discussed further in the next section.

\subsection{Expression of Recombinant Phytase from M. smegmatis in E. coli DH5 $\alpha$}

Phytase activity has been well documented in E. coli. Hence, in our protein expression study, two controls were used: E. coli DH5 $\alpha$ that was not transformed with pMSuia plasmid and cells with pMSuia plasmid but not induced with L-arabinose. Protein expression was carried out in $50 \mathrm{ml} \mathrm{LB}$ broth containing $100 \mu \mathrm{g} / \mathrm{ml}$ ampicillin. $\mathrm{L}$-arabinose $(0.2 \% \mathrm{w} / \mathrm{v})$ was added to the growth culture when the $\mathrm{OD}_{600 \mathrm{~nm}}$ reached 0.6. Since the expression of phyMS gene in pMSuia plasmid construct is regulated by araC, a transcriptional regulator that forms a complex with L-arabinose, in the absence of L-arabinose ideally no transcription of the phyMS gene should occur. The specific activity of $5.4 \mathrm{U} / \mathrm{mg}$ for crude $M$. smegmatis phytase from pMSuia was significantly higher than both controls (Table 1) indicating that the active recombinant $M$. smegmatis phytase was successfully expressed in $E$. coli DH5 $\alpha$. 

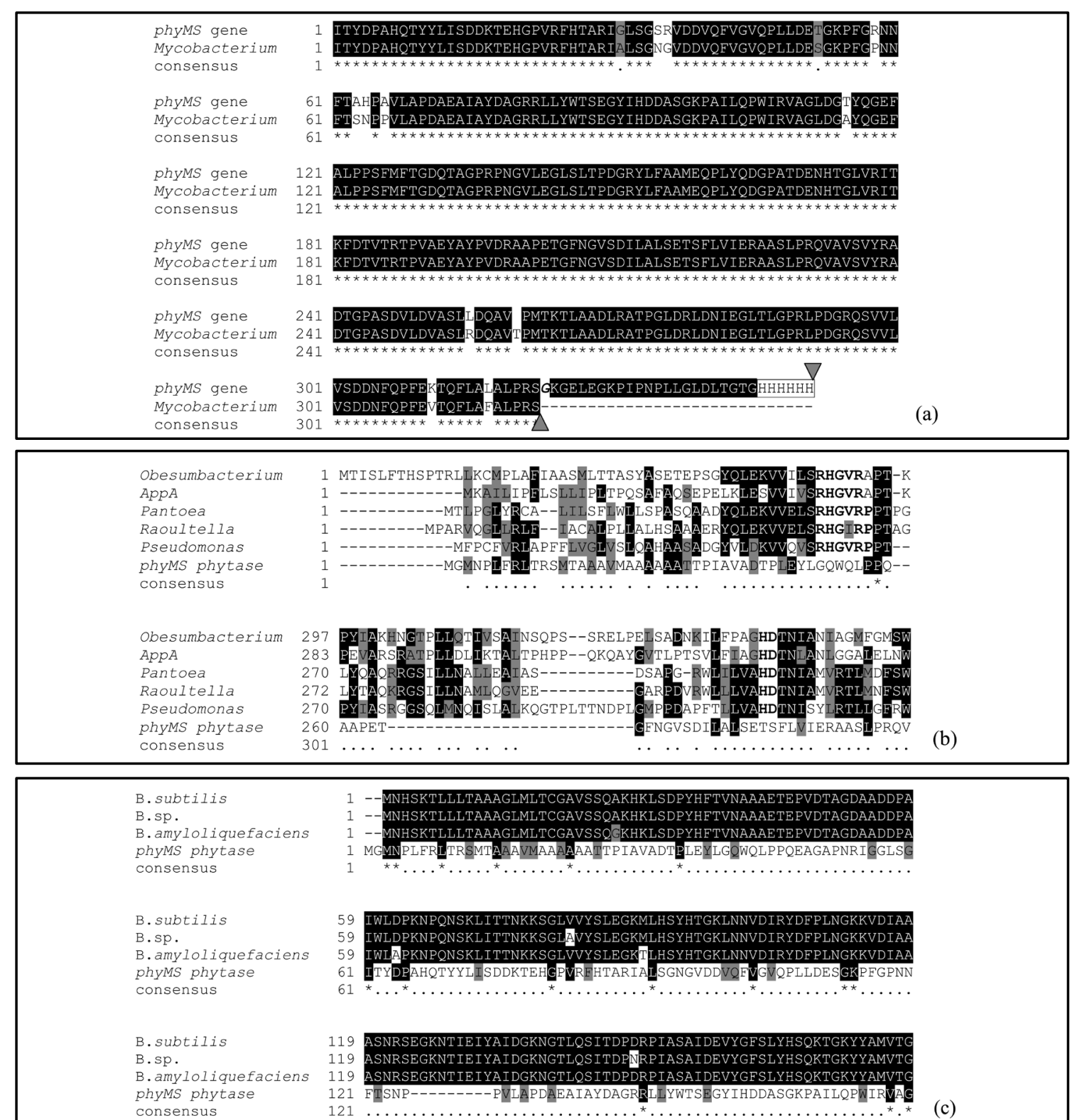

(c)

Note. (a) The amino acid sequence is presented from 5' to 3' end. The identical residues are represented in black shade and an asterisk ( $\left.{ }^{*}\right)$. The asterisk also shows the consensus between sequences. The different amino acids but share common properties are shaded in grey color and a dot (.). The sequence encoding the 6xHis tag is boxed. The introduced amino acid is italic and bolded. The grey filled triangles indicate stop codon. (b) The amino acid sequences of these known acidic phytases were obtained from NCBI nucleotide databases with the following accession numbers: AAQ90419.1 Obesumbacterium proteus; ADZ99368.1 Pantoea agglomerans; AAN77879.1 Pseudomonas syringae; CAE01322.1 Raoultella terrigena; AAN28334.1 AppA Escherichia coli. Black-shaded amino acids represent identical residues whereas grey-shaded amino acids represent similar residues. Invariant amino acids in all sequences are indicated by an asterisk $\left({ }^{*}\right)$ while positions with conservative substitutions are indicated by dot (.). Gaps in the sequence to facilitate alignment are indicated by hyphen (-). The most commonly conserved regions in acidic and alkaline phytases are highlighted in bold upper case capital letter. (c) The amino acid sequences of these known alkaline phytases were obtained from NCBI nucleotide databases with the following accession numbers: B. subtilis (ACR78677.1 Bacillus subtilis); B.sp (AAC38573.1 Bacillus sp. DS11); B. amyloliquefaciens (AAL25193.3 Bacillus amyloliquefaciens). Black-shaded amino acids represent identical residues whereas grey-shaded amino acids represent similar residues. Invariant amino acids in all sequences are indicated by an asterisk $(*)$ while positions with conservative substitutions are indicated by dot (.). Gaps in the sequence to facilitate alignment are indicated by hyphen (-). The most commonly conserved regions in acidic and alkaline phytases are highlighted in bold upper case capital letter. Most of the alkaline phytases from Bacillus species are nearly identical.

Figure 1. ClustalW and Box-shade representation (a) deduced amino acid sequence of phyMS gene in pBAD-TOPO expression vector and available $M$. smegmatis str. MC2 155 (accession number YP_885178.1) phytase amino acid sequence in NCBI protein database and multiple alignment of $M$. smegmatis phytase and (b) acidic phytase sequences from several bacteria species, and (c) alkaline phytase sequences from several bacteria species. 
Table 1. Phytase expression study showing phytase activity (U/ml) with and without L-arabinose induction.

\begin{tabular}{ccccc}
\hline Source & Volume $(\boldsymbol{\mu l})$ & Protein content $(\boldsymbol{\mu g} / \boldsymbol{\mu l})$ & Phytase activity $^{*}(\mathrm{U} / \mathbf{m l})$ & Specific activity $(\mathrm{U} / \mathbf{m g})$ \\
\hline $\begin{array}{c}\text { E. coli DH5 } \alpha \text { with pMSuia plasmid } \\
\begin{array}{c}\text { E. coli DH5 } \alpha \text { with pMSuia plasmid } \\
\text { but not induced }\end{array}\end{array}$ & 50 & 0.597 & 3.27 & 5.474 \\
\begin{tabular}{c} 
E. coli DH5 $\alpha$ only \\
\hline
\end{tabular} & 50 & 0.206 & 0.091 & 0.442 \\
\hline
\end{tabular}

"conducted in $100 \mathrm{mM}$ sodium acetate, $\mathrm{pH} 4.5$ and $55^{\circ} \mathrm{C}$.

For further confirmation, the crude $M$. smegmatis phytase was analyzed by SDS-PAGE and Western blot for the presence of the desired product. Coomassie stained SDS-polyacrylamide gel showed that a thick band with a $\mathrm{M}_{\mathrm{r}}$ of $\sim 45 \mathrm{kDa}$ was observed on the pMSuia plasmid containing cells induced with $0.02 \% \mathrm{w} / \mathrm{v}$ L-arabinose and both controls (pMSuia plasmid containing cells but not induced and E. coli DH5 $\alpha$ free plasmid) (Figure 2(a)). The thick bands on the controls might represent $E$. coli phytase with approximate $\mathrm{M}_{\mathrm{r}}$ of $46 \mathrm{kDa}$ or other proteins of similar size. The presence of $M$. smegmatis phytase was clearly revealed by Western blot analysis since antiHis IgG antibody binds specifically to the 6xHis tag in recombinant M. smegmatis phytase (Figure 2(b)). Weak signal was detected from the non-induced culture while no signal was detected from the plasmid free $E$. coli DH5 $\alpha$. The Western blot showed that the size of the recombinant M. smegmatis phytase was approximately $\sim 45$ $\mathrm{kDa}$ which was very close to the predicted size of $44.1 \mathrm{kDa}$ by $\mathrm{pI} / \mathrm{Mw}$ tool in EXPASY

(http://expasy.org/tools/pi tool.html). The M. smegmatis phytase was comparable to the other bacterial phytases such as Bacillus sp. (44 kDa) [16], Pseudomonas syringae (45 kDa) [17] and Obesumbacterium proteus (45 kDa) [18]. Other bacterial phytases such as E.coli, Klebsiella sp., and Pantoea agglomerans demonstrated molecular masses between $40 \mathrm{kDa}$ to $42 \mathrm{kDa}$. Large molecular masses of bacterial phytases were reported from Lactobacillus pentosus (69 $\mathrm{kDa})$ [19].

\subsection{Protein Purification and Molecular Properties}

The crude $M$. smegmatis phytase was easily recovered following cell lysis by sonication and centrifugation. The supernatant from the centrifugation step was loaded onto a Ni-NTA affinity column and $M$. smegmatis phytase eluted as a single sharp activity peak from the affinity chromatography column exhibited an activity of $\sim 233$ $\mathrm{U} / \mathrm{mg}$ with a 24 fold purification and a recovery of 56\%. The affinity purified $M$. smegmatis phytase appeared as a homogeneous single protein band of $\sim 45 \mathrm{kDa}$ by SDS-PAGE (Figure 3).

\section{5. pH Profile}

The standard phytase assay was performed using a variety of buffers from $\mathrm{pH} 2.0$ to 11.0. The purified enzyme exhibited bi-hump pH optima at $\mathrm{pH} 3$ and $\mathrm{pH} 7$ (Figure 4(a)). M. smegmatis phytase was virtually inactive at $\mathrm{pH}$ more than 10 and only $20 \%$ activity is retained at $\mathrm{pH}$ 2.0. Nevertheless, the recombinant $M$. smegmatis phytase retains more than $50 \%$ of its activity from $\mathrm{pH} 3$ to $\mathrm{pH} 8$.

The phenomenon of bi-hump pH optima had been also reported for Aspergillus niger phytase which exhibits optimum activity at $\mathrm{pH} 2.6$ to $\mathrm{pH} 5.0$ [20]. Several other fungal strains were also reported to exhibit two pH optimal such as Aspergillus ficuum (pH 2.2 and $\mathrm{pH}$ 5.5) [21], and Aspergillus fumigatus (pH 4 and $\mathrm{pH}$ 6) [22]. Nevertheless, most of these fungi phytases virtually lost their activity when the $\mathrm{pH}$ value reached 7.0. On the other hand, $M$. smegmatis phytase exhibited considerable stability over the $\mathrm{pH}$ range of 2.0 to 9.0 which manifested a better $\mathrm{pH}$ tolerance than Aspergillus phytases. The high activity over broad $\mathrm{pH}$ range would allow $M$. smegmatis phytase to function well in the stomach and small intestine of animals and are essential features for any potential use as animal feed additives. Thus, the ability to remain active in both acidic and slight alkaline conditions makes $M$. smegmatis phytase not just a potential candidate for feed additives in poultry industry but for aquaculture as well. In aquaculture, the efficacy of phytase differs in agastric fish where the digestive tract $\mathrm{pH}$ is $\sim 6.5-8.4$ [23] whereas the $\mathrm{pH}$ of digestive tract for gastric fish is $\sim 2.7$ for [24]. Since, the optimum $\mathrm{pH}$ range of microbial phytases is between 2.0 and 6.0, most of the microbial phytases exhibited poor efficacy in agastric fish. Hence, acidifiers such as citric acid, fumaric acid, lactic acid and formic acid were added in their diet to regulate the digestive tract $\mathrm{pH}$ to phytase optimal $\mathrm{pH}$, to ultimately amplify the activity of exogenous 


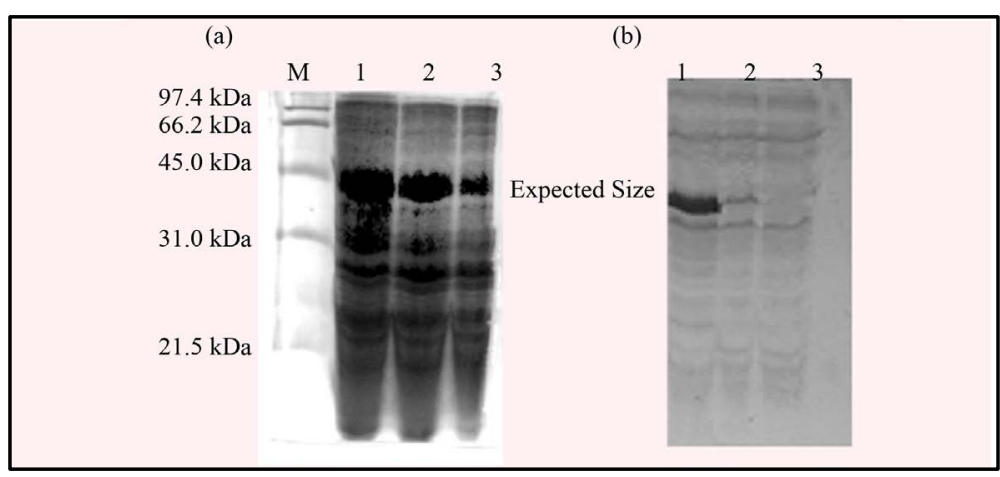

Figure 2. (a) SDS-PAGE analysis of phytase expression (b) and Western blot analysis of the recombinant $M$. smegmatis phytase with $6 x$ His tag. Lane $\mathrm{M}$, Low $\mathrm{M}_{\mathrm{r}}$ standard protein marker (Biorad, USA); lane (a)1, crude protein from pMSuia plasmid induced with $0.2 \% \mathrm{w} / \mathrm{v}$ L-arabinose; lane (a)2, crude protein from pMSuia plasmid without L-arabinose induction; lane (a)3, E. coli DH5a devoid of pMSuia plasmid; lane (b)1: Western blot of the recombinant $M$. smegmatis phytase induced with $0.2 \% \mathrm{w} / \mathrm{v}$ L-arabinose; lane (b)2: Western blot of the recombinant $M$. smegmatis phytase without L-arabinose induction; lane (b)3: Western blot of the E. coli DH5 $\alpha$ free of pMSuia plasmid.

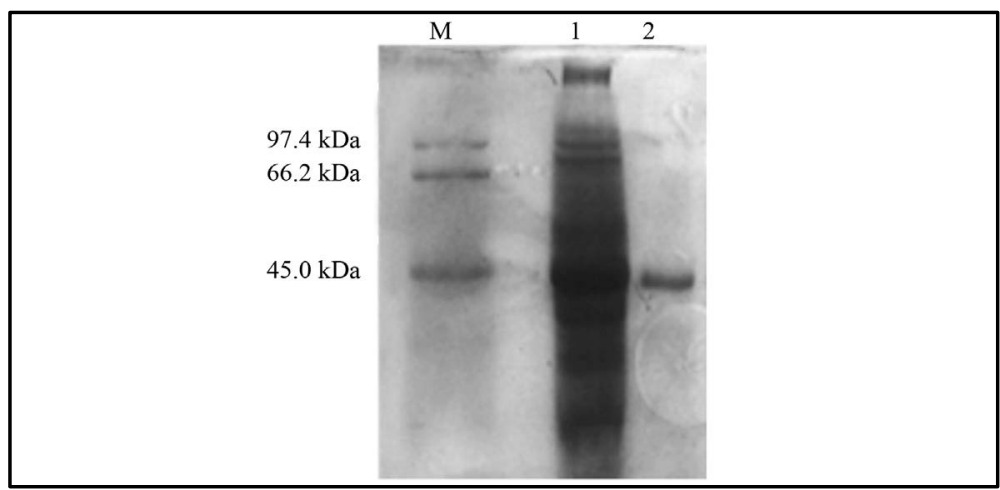

Figure 3. Electrophoretic analysis of the affinity purified recombinant $M$. smegmatis phytase from induced E. coli $\mathrm{DH} 5 \alpha$ containing pMSuia plasmid on $12 \%$ SDS-PAGE and stained with Coomassie blue; Lane M: Low $\mathrm{M}_{\mathrm{r}}$ protein standard marker, Lane 1: Crude sample, Lane 2: purified recombinant $M$. smegmatis phytase from Ni-NTA affinity column.

phytase [25]. The additional of acidifier will definitely increase the levy surplus in aqua farming activity. Thus, M. smegmatis phytase with broader $\mathrm{pH}$ range would be the best alternative to cater this problem.

\subsection{Temperature Optimum and Thermal Stability}

The temperature profile of the purified phytase was determined from $40^{\circ} \mathrm{C}$ to $100^{\circ} \mathrm{C}$ using the standard phytase assay. The optimum temperature was $60^{\circ} \mathrm{C}$ for both $\mathrm{pH} 3$ and 7 (Figure 4(b)). In the acidic environment $M$. smegmatis phytase exhibited slightly higher optimum temperature compared to the enzyme in alkaline condition. However, the enzyme in $\mathrm{pH} 7$ was slightly more stable compared to the $M$. smegmatis phytase suspended in acidic conditions. The alkaline conditions appeared to improve the stability of the enzyme as evidenced from more than $60 \%$ residual enzyme activity retained at temperature above $70^{\circ} \mathrm{C}$.

The thermal stability of the purified enzyme was evaluated by incubation at different temperatures, cooled to $4^{\circ} \mathrm{C}$ and assayed using the standard phytase assay. The enzyme maintained more than $80 \%$ residual activity even after incubation for $60 \mathrm{~min}$ at $60^{\circ} \mathrm{C}$. Meanwhile, almost $60 \%$ residual activity was retained from the initial activity when exposed to $70^{\circ} \mathrm{C}$ for $60 \mathrm{~min}$ and more than $30 \%$ retained when exposed to $80^{\circ} \mathrm{C}$ and $90^{\circ} \mathrm{C}$ for 60 min, respectively (Figure 4(c)). 


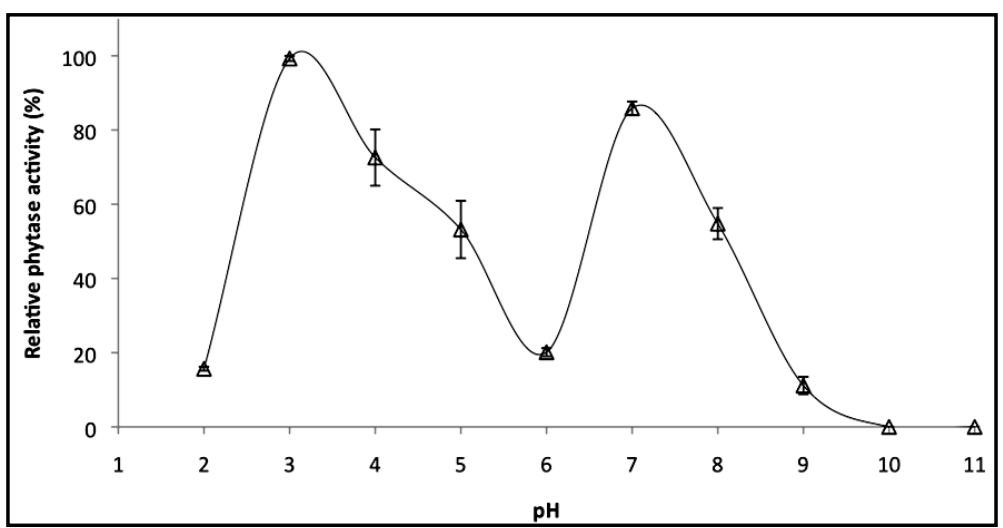

(a)

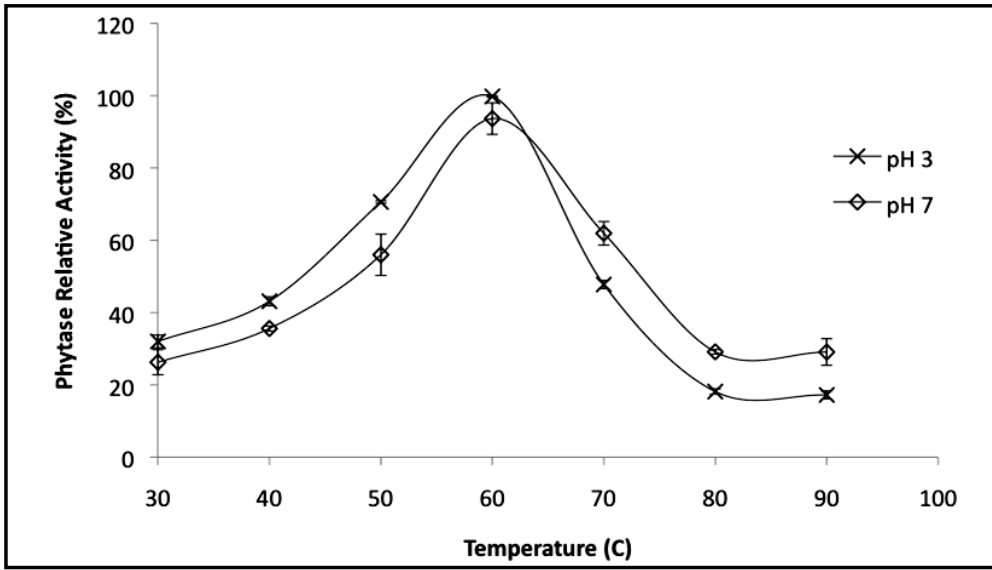

(b)

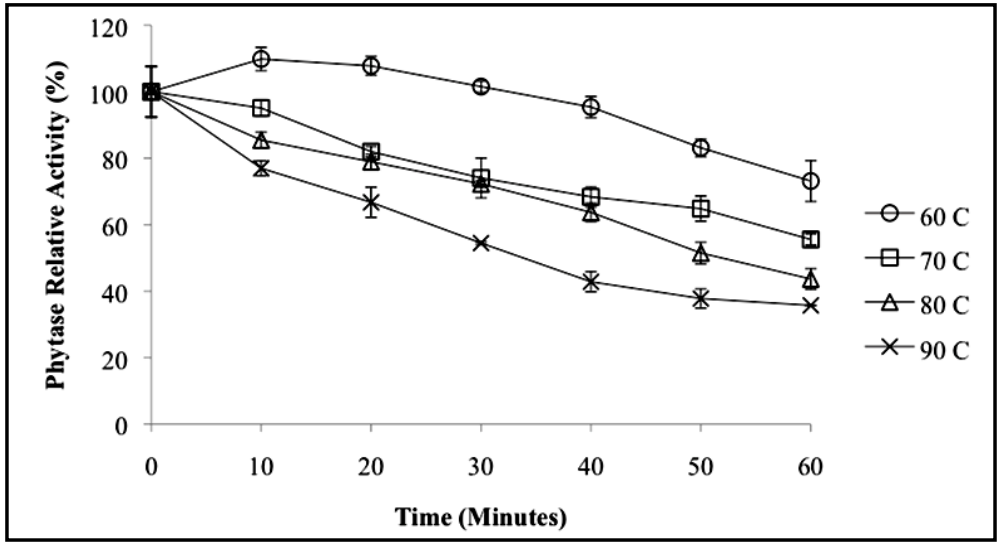

(c)

Figure 4. (a) Effect of $\mathrm{pH}$ on hydrolytic activity of purified recombinant $M$. smegmatis phytase. (b) The temperature activity profile of purified recombinant $M$. smegmatis phytase. (The relative activity is a comparison between untreated phytase corresponding to the $100 \%$ value). (c) Thermostability of purified recombinant $M$. smegmatis phytase. (The relative activity is a comparison between untreated phytase corresponding to the $100 \%$ value).

Purified M. smegmatis phytase optimum activity at $60^{\circ} \mathrm{C}$ is comparable to several phytases such as $A$. fumigatus [17], Pantoea agglomerans [11] and Pichia anomala [26]. High optimum temperature is desirable for better enzyme thermostability. Thermostability is a particularly important issue since feed pelleting is commonly 
performed at temperatures between $65^{\circ} \mathrm{C}$ and $95^{\circ} \mathrm{C}$ [27]. Although phytase inclusion using an after-spray apparatus for pelleted diets and/or chemical coating of phytase may help bypass or overcome the heat destruction of the enzyme, phytases resisting high temperatures will no doubt be better candidates for feed supplements. Compared to the commercially available phytases from A. niger, P. lycii and E. coli, the purified M. smegmatis phytase exhibits a slightly higher thermal stability. When exposed for $60 \mathrm{~min}$ at $70^{\circ} \mathrm{C}$, the purified phytase retained $60 \%$ of the initial activity, whereas the enzymes from A. niger retained only $40 \%$ and the phytase from $P$. lycii was completely inactivated after $15 \mathrm{~s}$ at $70^{\circ} \mathrm{C}$ [28]. Meanwhile, only $27 \%$ residual activity of $E$. coli phytase were reported after $10 \mathrm{~min}$ exposure at $85^{\circ} \mathrm{C}$ [29], compared to PhyMS phytase that retained $30 \%$ from the initial activity after heating for $60 \mathrm{~min}$ at $90^{\circ} \mathrm{C}$. The phytases most resistant to high temperatures reported so far have been isolated from Pichia anomala [26], Schwanniomyces castellii [30], and Lactobacillus sanfranciscensis [31]. Incubation of these enzymes at $70^{\circ} \mathrm{C}$ for $10 \mathrm{~min}$ did not result in any significant loss of activity and the phytase from $P$. anomala was even reported to tolerate a 30 hours treatment at $70^{\circ} \mathrm{C}$ without any loss of activity [26]. However, none of these phytases had found in commercial applications.

\subsection{Substrate Specificity}

The hydrolytic activity of purified $M$. smegmatis phytase on several phosphate conjugates was tested in $50 \mathrm{mM}$ sodium acetate $(\mathrm{pH} \mathrm{3})$ and glycine- $\mathrm{HCl}(\mathrm{pH} 7)$ buffer. The relative rate of hydrolysis of various substrates is summarized in Table 2. The purified enzyme showed considerably broad substrate specificity at $\mathrm{pH} 3$ and 7. Wyss et al. [33] suggested that phytases with broad substrate specificity are better suited for animal nutrition purposes than phytases with narrow substrate specificity. Broad substrate specificity is usually reported in higher organisms such as fungi and yeast (Table 3). Nevertheless, bacteria producing phytases from Lactobacillus

Table 2. Michaelis constant for recombinant M. smegmatis phytase and selected broad substrate specificity phytases.

\begin{tabular}{|c|c|c|c|}
\hline Source & pH & $\boldsymbol{K}_{\boldsymbol{m}}(\mathbf{m M})$ (Na-phytate) & Reference \\
\hline \multirow{2}{*}{ Recombinant $M$. smegmatis phytase ${ }^{\mathrm{a}}$} & 3.0 & 0.105 & \multirow{2}{*}{ this study } \\
\hline & 7.0 & 0.099 & \\
\hline A. niger $^{\mathrm{b}}$ & 5.05 & $0.929 \times 10^{-3}$ & [20] \\
\hline A. oryzae ${ }^{c}$ & 5.5 & 0.33 & {$[36]$} \\
\hline A. ficuum $^{\mathrm{d}}$ & 2.5 & 0.103 & {$[21]$} \\
\hline
\end{tabular}

Note. Determined in: ${ }^{\mathrm{a}} 100 \mathrm{mM} \mathrm{Na}-\mathrm{HCl}(\mathrm{pH} 3)$ and $100 \mathrm{mM}$ Tris- $\mathrm{HCl}(\mathrm{pH} 7)$ at $60^{\circ} \mathrm{C} ;{ }^{\mathrm{b}} 200 \mathrm{mM}$ Na-acetate (pH 5.05) at 55 ${ }^{\circ} \mathrm{C}$; $100 \mathrm{mM}$ acetate buffer (pH 5.5) at $37^{\circ} \mathrm{C} ;{ }^{\mathrm{d}} 50 \mathrm{mM}$ Na-acetate buffer (pH 5.0) at $58^{\circ} \mathrm{C}$.

Table 3. Substrate specificity of purified recombinant $M$. smegmatis phytase at $\mathrm{pH} 3$ and $\mathrm{pH} 7$ compared to selected microbial phytases.

\begin{tabular}{|c|c|c|c|c|c|c|c|}
\hline \multirow{3}{*}{ Substrate } & \multicolumn{7}{|c|}{ Relative Activity (\%) } \\
\hline & \multicolumn{2}{|c|}{$\begin{array}{l}\text { Recombinant } \\
\text { M. smegmatis } \\
\text { Phytase }\end{array}$} & \multirow{2}{*}{$\begin{array}{c}\text { E. coli [32] } \\
\text { pH } 4.5\end{array}$} & \multirow{2}{*}{$\begin{array}{l}\text { A. niger } \\
{[20]} \\
\text { pH } 5.05\end{array}$} & \multirow{2}{*}{$\begin{array}{c}\text { L. sanfranciscensis } \\
{[31]} \\
\mathrm{pH} 4.0\end{array}$} & \multirow{2}{*}{$\begin{array}{c}\begin{array}{c}\text { A. oryzae } \\
\text { [30] }\end{array} \\
\text { pH } 4.5\end{array}$} & \multirow{2}{*}{$\begin{array}{c}\text { L. pentosus } \\
{[29]} \\
\text { pH } 5\end{array}$} \\
\hline & pH 3 & $\mathrm{pH} 7$ & & & & & \\
\hline Sodium phytate & 100.00 & 100.00 & 100 & 100 & 100 & 100 & 100 \\
\hline AMP & 31.80 & 28.70 & 0 & 2.15 & 96.5 & - & - \\
\hline ADP & 80.19 & 79.26 & 0 & 1.58 & 98.5 & - & - \\
\hline ATP & 81.56 & 82.74 & 0 & 2.44 & 100 & - & - \\
\hline NADP & 17.50 & 16.50 & 0 & 3.01 & - & - & - \\
\hline Naphthyl acid phosphate & 34.34 & 33.34 & 0.7 & 1.58 & - & - & - \\
\hline D-fructose 1,6 biphosphate & 98.36 & 99.00 & 8.5 & - & 12.1 & - & 1599 \\
\hline p-Nitrophenyl phosphate & 0.00 & 0.00 & 12.3 & 1.72 & 124.2 & 73.1 & 1655.6 \\
\hline Pyridoxal-5-phosphate & 0.00 & 0.00 & 0 & - & - & - & - \\
\hline
\end{tabular}

${ }^{*}$ Activities were expressed as a percentage of the activity obtained against sodium phytate, which was given a value of $100 \%$. 
sanfancis [31] and Lactobacillus plantarum [34] have also exhibited high activity in a variety of phosphate conjugates.

Unfortunately, the broad substrate specificity regularly incorporated with low specific activity [33]. Only phytases from Lactobacillus pentosus and Aspergillus oryzae displayed broad substrate specificity with higher $\mathrm{K}_{\mathrm{m}}$ values for sodium phytate; $0.23 \mathrm{mM}$ for Lactobacillus pentosus [35] and $0.33 \mathrm{mM}$ for Aspergillus oryzae [36]. Nevertheless, the $\mathrm{K}_{\mathrm{m}}(0.105 \pm 0.016 \mathrm{mM})$ and the maximum reaction velocity $V_{\max }(26.93 \pm 1.21 \mathrm{mM} / \mathrm{min})$ of $M$. smegmatis phytase is considerably higher for phytases that exhibited broad substrate specificity (Table 2).

To recapitulate, the novel $M$. smegmatis phytase reported here displayed some characteristics distinct from bacterial and fungal phytases previously reported in the literature. It manifested the advantageous properties being relatively thermostable, exhibiting broad substrate specificity and considerable stability over a broad $\mathrm{pH}$ range. It signifies that $M$. smegmatis phytase has a great potential for commercial interest as an animal feed additive in poultry and aquaculture industries. Since this novel phytase demonstrated outstanding properties, further studies are under way to elucidate the structure-function relationship of M. smegmatis phytase.

\section{Acknowledgements}

This research was supported by a financial research grant from the Ministry of Science, Technology and Innovation, Malaysia (grant no. 07-01-08-EIB011). We thank researchers in the Bioprocess and Molecular Engineering Research Unit, International Islamic University Malaysia for helpful discussions. The technical assistance of Nor Hasima Mahmod is greatly acknowledged.

\section{References}

[1] Haefner, S., Knietsch, A., Scholten, E., Braun, J., Lohscheidt, M. and Zelder, O. (2005) Biotechnological Production and Applications of Phytases. Applied Microbiology and Biotechnology, 68, 588-597. http://dx.doi.org/10.1007/s00253-005-0005-y

[2] Greiner, R. and Konietzny, U. (2006) Phytase for Food Application. Food Technology and Biotechnology, 44, 125140.

[3] Haros, M., Rosell, C.M. and Benedito, C. (2001) Fungal Phytase as a Potential Breadmaking Additive. European Food Research and Technology, 213, 317-322. http://dx.doi.org/10.1007/s002170100396

[4] Kumar, V., Sinha, A.K., Makkar, H.P.S. and Becker, K. (2010) Dietary Roles of Phytate and Phytase in Human Nutrition: A Review. Food Chemistry, 120, 945-959. http://dx.doi.org/10.1016/j.foodchem.2009.11.052

[5] Drakakaki, G., Marcel, S., Glahn, R.P., Lund, L., Periagh, S., Fischer, R., Christou, P. and Stoger, E. (2005) Endosperm Specific Co-Expression of Recombinant Soybean Ferritin and Aspergillus Phytase in Maize Results in Significant Increases in the Levels of Bioavailable Iron. Plant Molecular Biology, 59, 869-880. http://dx.doi.org/10.1007/s11103-005-1537-3

[6] Kim, Y.O., Lee, J.K., Kim, H.K., Yu, J.H. and Oh, T.K. (1998) Cloning of the Thermostable Phytase (Phy) from Bacillus sp. DS11 and Its Overexpression in Escherichia coli. FEMS Microbiology Letters, 162, 185-191. http://dx.doi.org/10.1111/j.1574-6968.1998.tb12997.x

[7] Kerovuo, J. and Tynkkynen, S. (2000) Expression of Bacillus subtilis Phytase in Lactobacillus plantarum 755. Letters in Applied Microbiology, 30, 325-329. http://dx.doi.org/10.1046/j.1472-765x.2000.00660.x

[8] Yip, W., Wang, L., Cheng, C., Wu, W., Lung, S. and Lim, B. (2003) The Introduction of a Phytase Gene from Bacillus subtilis Improved the Growth Performance of Transgenic Tobacco. Biochemical and Biophysical Research Communications, 310, 1148-1154. http://dx.doi.org/10.1016/j.bbrc.2003.09.136

[9] Sambrook, J., Fritschi, E.F. and Maniatis, T. (1989) Molecular Cloning: A Laboratory Manual. Cold Spring Harbor Laboratory Press, New York.

[10] Dechow, F.J. (1989) Separation and Purification Techniques in Biotechnology. Noyes Publications, New Jersey, 416478.

[11] Greiner, R. (2004) Purification and Properties of a Phytate-Degrading Enzyme from Pantoea agglomerans. Protein Journal, 23, 567-576. http://dx.doi.org/10.1007/s10930-004-7883-1

[12] Heinonen, J.K. and Lathi, R.J. (1981) A New and Convenient Colometric Determination of Inorganic Orthophosphate and Its Application to the Assay of Inorganic Pyrophosphatase. Analytical Biochemistry, 113, 313-317. http://dx.doi.org/10.1016/0003-2697(81)90082-8

[13] Ostanin, K. and Van Etten, R.L. (1993) Asp304 of Escherichia coli Acid Phosphatase Is Involved in Leaving Group Protonation. The Journal of Biological Chemistry, 268, 20778-20784. 
[14] Lei, X.G. and Porres, J.M. (2003) Phytase Enzymology, Applications and Biotechnology. Biotechnology Letters, 25, 1787-1794. http://dx.doi.org/10.1023/A:1026224101580

[15] Kerovuo, J., Lauraeus, M., Nurminen, P., Kalkkinen, N. and Apajalahti, J. (1998) Isolation, Characterization, Molecular Gene Cloning and Sequence of a Novel Phytase from Bacillus subtilis. Applied and Environmental Microbiology, 64, 2079-2085.

[16] Kim, Y.O., Kim, H.K., Bae, K.S., Yu, J.H. and Oh, T.K. (1998). Purification and Properties of a Thermostable Phytase from Bacillus sp.DS11. Enzyme and Microbial Technology, 22, 2-7. http://dx.doi.org/10.1016/S0141-0229(97)00096-3

[17] Cho, J.S., Lee, C.W., Kang, S.H., Lee, J.C., Bok, J.D., Moon, Y.S., Lee, H.G., Kim, S.C. and Choi, Y.J. (2003) Purification and Characterization of a Phytase from Pseudomonas syringae MOK1. Current Microbiology, 47, 290-294. http://dx.doi.org/10.1007/s00284-002-3966-4

[18] Zinin, N.V., Serkina, A.V., Gelfand, M.S., Shevelev, A.B. and Sineoky, S.P. (2004) Gene Cloning, Expression and Characterization of Novel Phytase from Obesumbacterium proteus. FEMS Microbiology Letters, 236, 283-290. http://dx.doi.org/10.1111/j.1574-6968.2004.tb09659.x

[19] Palacios, M.C., Haros, M., Rosell, C.M. and Sanz, Y. (2005) Characterization of an Acid Phosphatase from Lactobacillus pentosus: Regulation and Chemical Properties. Journal of Applied Microbiology, 98, 229-237. http://dx.doi.org/10.1111/j.1365-2672.2004.02447.x

[20] Sariyska, M.V., Gargova, S.A., Koleva, L.A. and Angelov, A.I. (2005) Aspergillus niger Phytase: Purification and Characterization. Biotechnology \& Biotechnological Equipment, 19, 98-105.

[21] Ullah, A.H.J. and Gibson, D.M. (1987) Extracellular Phytase (E.C. 3.1.3.8) from Aspergillus ficuurn NRRL 3135: Purification and Characterization. Preparative Biochemistry and Biotechnology, 17, 63-91.

[22] Pasamontes, L., Haiker, M., Wyss, M., Tessier, M., van Loon, A.P.G.M. (1997) Gene Cloning, Purification, and Characterization of a Heat-Stable Phytase from the Fungus Aspergillus fumigatus. Applied and Environmental Microbiology, 63, 1696-1700.

[23] Cao, L., Wang, W., Yang, C., Yang, Y., Diana, J., Yakuptiyage, A., Luo, Z. and Li, D. (2007) Application of Microbial Phytase in Fish Feed. Enzyme and Microbial Technology, 40, 497-507. http://dx.doi.org/10.1016/j.enzmictec.2007.01.007

[24] Luckstadt, C. (2012) Acidification in Monogastric Fish: Limits and Potential. AQUA Culture Asia Pacific Magazine, 38-39.

[25] Baruah, K., Pal, A.K., Sahu, N.P., Jain, K.K., Mukherjee, S.C. and Debnath, D. (2005) Dietary Protein Level, Microbial Phytase, Citric Acid and Their Interactions on Bone Mineralization of Labeo rohita (Hamilton) Juveniles. Aquaculture Research, 36, 803-812. http://dx.doi.org/10.1111/j.1365-2109.2005.01290.x

[26] Vohra, A. and Satyanarayana, T. (2002) Statistical Optimization of the Medium Components by Response Surface Methodology to Enhance Phytase Production by Pichia anomala. Process Biochemistry, 37, 999-1004. http://dx.doi.org/10.1016/S0032-9592(01)00308-9

[27] Konietzny, U. and Greiner, R. (2004) Bacterial Phytase: Potential Application, in Vivo Function and Regulation of Its Synthesis. Brazilian Journal of Microbiology, 35, 11-18. http://dx.doi.org/10.1590/S1517-83822004000100002

[28] Ullah, A.H.J., Sethumadhavan, K., Mullaney, E.J., Ziegelhoffer, T. and Philips, S.A. (2003) Fungal phyA Gene Expressed in Potato Leaves Produces Active and Stable Phytase. Biochemical and Biophysical Research Communications, 306, 603-609. http://dx.doi.org/10.1016/S0006-291X(03)01002-7

[29] Garrett, J.B., Kretz, K.A., O’Donoghue, E., Kerovuo, J., Kim, J., Barton, N.R., Hazlewood, G.P., Short, J.M., Robertson, D.E., Gray, K.A. (2004) Enhancing the Thermal Tolerance and Gastric Performance of a Microbial Phytase for Use as a Phosphate-Mobilizing Monogastric-Feed Supplement. Applied and Environmental Microbiology, 70, 30413046. http://dx.doi.org/10.1128/AEM.70.5.3041-3046.2004

[30] Segueilha, L., Lambrechts, C., Boze, H., Moulin, G. and Galzy, P. (1992) Purification and Properties of the Phytase from Schwanniomyces castellii. Journal of Fermentation and Bioengineering, 7, 7-11. http://dx.doi.org/10.1016/0922-338X(92)90259-W

[31] Angelis, M.D., Gallo, G., Corbo, M.R., McSweeney, P.L.H., Faccia, M., Giovine, M. and Gobbetti, M. (2003) Phytase Activity in Sourdough Lactic Acid Bacteria: Purification and Characterization of Phytase from Lactobacillus sanfranciscensis CB1. International Journal of Food Microbiology, 87, 259-270. http://dx.doi.org/10.1016/S0168-1605(03)00072-2

[32] Greiner, R., Konietzny, U. and Jany, K.D. (1993) Purification and Characterization of Two Phytases from Escherichia coli. Archives of Biochemistry and Biophysics, 303, 107-113. http://dx.doi.org/10.1006/abbi.1993.1261

[33] Wyss, M., Brugger, R., Kronenberger, A., Remy, R., Fimbel, R., Oesterhelt, G., Lehmann, M., van Loon, A.P.G.M. (1999) Biochemical Characterization of Fungal Phytases (myo-Inositol Hexakisphosphate Phosphohydrolases): Cata- 
lytic Properties. Applied and Environmental Microbiology, 65, 367-373.

[34] Zamudio, M., Gonzalez, A. and Medina, J.A. (2000) Lactobacillus plantarum Phytase Activity Is Due to the NonSpecific Acid Phosphatase. Letters in Applied Microbiology, 32, 181-184. http://dx.doi.org/10.1046/j.1472-765x.2001.00890.x

[35] Palacios, M.C., Haros, M., Rosell, C.M. and Sanz, Y. (2005) Characterization of an Acid Phosphatase from Lactobacillus pentosus: Regulation and Chemical Properties. Journal of Applied Microbiology, 98, 229-237. http://dx.doi.org/10.1111/j.1365-2672.2004.02447.x

[36] Shimizu, M. (1993) Purification and Characterization of Phytase and Acid Phosphatase Produced by Aspergillus oryzae K1. Bioscience, Biotechnology, and Biochemistry, 57, 1364-1365. http://dx.doi.org/10.1271/bbb.57.1364 